\title{
The Role of Architecture in the Process of Moving towards Sustainable Development
}

\section{Mohammadhossein Azizibabani*, Marjan Dehghani}

Housing Foundation of Islamic Revolution, Tehran, Iran

*Corresponding author: H.azizi66@hotmail.com

Гrossef http://dx.doi.org/10.5755/j01.sace.20.3.18406
Environmental, social, and cultural problems arose in the twentieth century as a result of acceleration of industrial growth of societies as well as economic inequalities. Lack of proper development patterns was the main factor demanding the introduction of the concept of sustainable development in the second half of the twentieth century. The construction industry, particularly the residential construction sector, was one of the major factors of energy consumption in the world. Therefore, inclusion of the issue of sustainable development in this area and coupling housing development policies with the goal of sustainable development was of particular importance. In this regard, sustainability, as one of the most influential disciplines in the field of architecture, played an important role in order to meet the objectives of sustainable development. This paper reviewed the concepts of sustainable development and sustainable design, and addressed them in the field of architecture. The research method was descriptive-analytic, based on library information, and extracted data from the case studies. In this regard, the movements related to sustainable architecture have been categorized and characteristics of a sustainable building in terms of sustainable development goals have been outlined. The results showed the importance of the architecture in the process of moving towards sustainability. Subsequently, an appropriate approach to meet the goals of sustainability in architectural design has been developed and potentials of this process to achieve sustainability have been mentioned.

Keywords: Sustainable development, Sustainable Architecture, Green Building, Renewable Energies, Building Information Modeling.

Industrial development of communities challenged the human race with serious problems in various fields of environment, culture, and society. The adverse effects coupled with the acceleration of industrial growth in the twentieth century became more evident. Environmental, economic and social issues such as increases in average global temperature, air and water pollution, and increased rate of migration from the countryside to towns, caused issues to arise due to differences in culture (Abel, 2003). The main factors raising the sustainable development in the second half of the twentieth century are lifestyle of people in the social sphere, the confrontation with the truth of fossil fuel resources finitude, and the increasing price of these resources in the field of economy (UNESCO, 2012). In this regard, most of the experts believe that the only way to eliminate the problems caused by the rapid growth of industrial societies and the advancement of technology is moving towards achieving the goals of sustainable development (Elington, 2004).
JSACE $3 / 20$

The Role of Architecture in the Process of Moving towards Sustainable Development

Received 2017/06/19

Accepted after revision 2017/11/03

\section{Introduction}

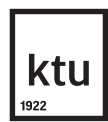

Journal of Sustainable Architecture and Civil Engineering Vol. 3 / No. 20 / 2017 pp. $25-35$

DOI 10.5755/j01.sace.20.3.18406 (c) Kaunas University of Technology 
Nowadays, $40 \%$ of energy consumption and $50 \%$ of global raw materials have been allocated to buildings (Attmann, 2010). Buildings are responsible for producing 36 percent of the waste in the world (Bauer and Mösle, 2010). Architecture as one of the most influential activities in the construction industry can play a significant role in increasing energy efficiency by switching to the use of renewable energies in buildings. Using these sources of energies is the prerequisite for moving towards sustainable development (Azizibabani, 2016). Thus addressing the issue of sustainable development in the field of architecture is leading to develop sustainable architecture criteria.

Sustainable architecture is an architecture that seeks to minimize the negative environmental impact of buildings by enhancing efficiency and moderation in the use of materials, energy, and development space (Sirija and Arch, 2013). Sustainable architecture is closely tied with the issue of reducing energy consumption and using renewable energies (Sassi, 2006). Some experts argued in this case that a large part of sustainable design is what we do through energy savings (Edwards, 2001). Although the principles of sustainable architecture include a wide range of applying the simplest methods to the newest sophisticated technologies (Gorji, 2010), in order to move towards the goals of sustainable development, the compliance of the method with social and cultural backgrounds of environment's users is also important (Azizibabani, 2016). The challenge of sustainable architecture is associated with finding a comprehensive solution for environmental considerations and at the same time getting the right level of quality of life and preservation of cultural, economic, and social values (Azizibabani, 2014). Therefore, in this paper, after reviewing the concepts of sustainable development, the authors categorize movements related to sustainable architecture and evaluate the principles and strategies of each one in order to achieve the various dimensions of sustainability in architecture. In addition, by specifying the definition of a sustainable building and considering it as a theoretical framework of the research, they provide solutions to supply sustainable development goals in the field of construction and design stage.

Therefore, the authors began to introduce and evaluate building information modelling (BIM) technique and its impact on achieving sustainability in the design process stage. In this context, sustainable buildings that the BIM technique played an important role in their design process have been studied, and analyzed. The results show the importance of implementation of design and construction methods to gain sustainability in buildings so a comprehensive model to meet sustainable development goals in the field of architecture has been developed.

The methodology of this research, which is conducted for practical use in the design process and to achieve sustainability in architectural design, is descriptive-analytic and is based on library information, and extracted data from case studies. The case studies have been mentioned in order to show the effects of design methods on the buildings sustainability.

Research Questions are:

How can an architect as one of the most influential people in the process of building design and consequently the construction industry, provide the necessary basis to put construction industry on the path towards sustainable development?

- What are the characteristics of a sustainable building that supply different dimensions of sustainable development goals?

How can an architect improve the performance of buildings in order to meet sustainability goals in the early stages of design?

The Concept of Sustainable Development
Sustainable development itself refers to "development that meets the needs of the present without compromising the ability of future generations to meet their own needs" (WCED, 1987). Although this concept was introduced almost thirty years ago, the subject is still current in today's society. In this regard, principles and dimensions of sustainable development became clearer so that nowadays the concept of sustainable development is being checked in three areas of environ- 
mental sustainability, economic sustainability and social sustainability (Spaiser and Ranganathan, 2016), which are as follows:

Environmental sustainability. An environmentally sustainable system must maintain a stable resource base, avoiding over-exploitation of renewable resource systems or environmental sink functions, and depleting non-renewable resources only to the extent that investment is made in adequate substitutes (Morelli, 2011). In this sense, in addition to quantitative and physical development, quality development is also of particular importance.

_ Economic sustainability. The economic dimension of sustainable development is linked with economic growth and other economic parameters. "The well-being of the individual and the community must be maximized through the efficient use of natural resources and equitable distribution of benefits and energy efficiency" (Zahrdi and Jafari, 2006).

_ Social sustainability. "Social sustainability is the main focus of the present and future generations (Murphy, 2012). It aims to meet the needs, improve the quality of life, and use all the capabilities and competence in self-improvement (Heerwagen and Zagreus, 2005), and has the criteria such as equal access to resources (social justice), ability to live well, health and social welfare security, raising of awareness and education, participation, and promotion of public relations" (Kefayati and Moztarzadeh, 2015).

As a result, the following definition of sustainable development, which has been referred to as different dimensions of sustainability, is considered a measure to assess the sustainability of buildings.

"Sustainable development is a process of change in which the exploitation of resources, the direction of investments, the orientation of technological development and institutional change are all in harmony and enhance both current and future potential to meet human needs and aspirations" (WCED, 1987).

In addition to the energy efficiency issue, which is associated with environmental side effects reduction (Hui, 2001), addressing aspects of sustainable development in the field of architecture, caused by providing users comfort and maintaining social, cultural, and economic issues, was considered as a prerequisite for a sustainable design (Azizibabani, 2016). This leads to the formulation of the definitions and components related to a kind of design, which is in line with the objectives of sustainable development that are known as sustainable design and the production of this kind of design in the field of architecture is sustainable architecture. The concept of sustainable architecture contains a wide range of definitions, techniques, and practices that multiple movements of different architectural approaches placed under this type of architecture. These movements can be divided into three general categories according to themes and approaches that have been adopted in the design. The first, which is related to the nineteenth century and the early decades of the twentieth century, considered architectural aesthetics topics and more concerned about harmony with the surrounding environment in terms of geometry and used materials. According to the terms of time, environmental pollution and energy issues have rarely been considered in this category. In this regard, we can mention the works of Antonio Gaudi as well as movements such as Art Nouveau. The use of renewable energy sources and natural resources conservation in other movements related to sustainable architecture, which are mostly related to the second half of the twentieth century, are of particular importance. There are two viewpoints in this regard. The first one is based on using new technologies in order to reduce energy consumption and exploit renewable energies (Sinopoli, 2010). These strategies can include broad ranges of building intelligentization methods in order to reduce energy consumption and efficient use of natural lighting, the use of active systems for renewable energies production, rainwater storage systems, and grey wastewater reuse (Clarke, 2008). The second viewpoint that is focused on using vernacular building materials and construction methods and passive heating and cooling systems in some cases totally rejects the technology. In the Table 1 movements, related to the sustainable archi-

\section{Sustainable Development and Architecture}


Table 1

Sustainable architecture movement (Azizibabani, 2014)

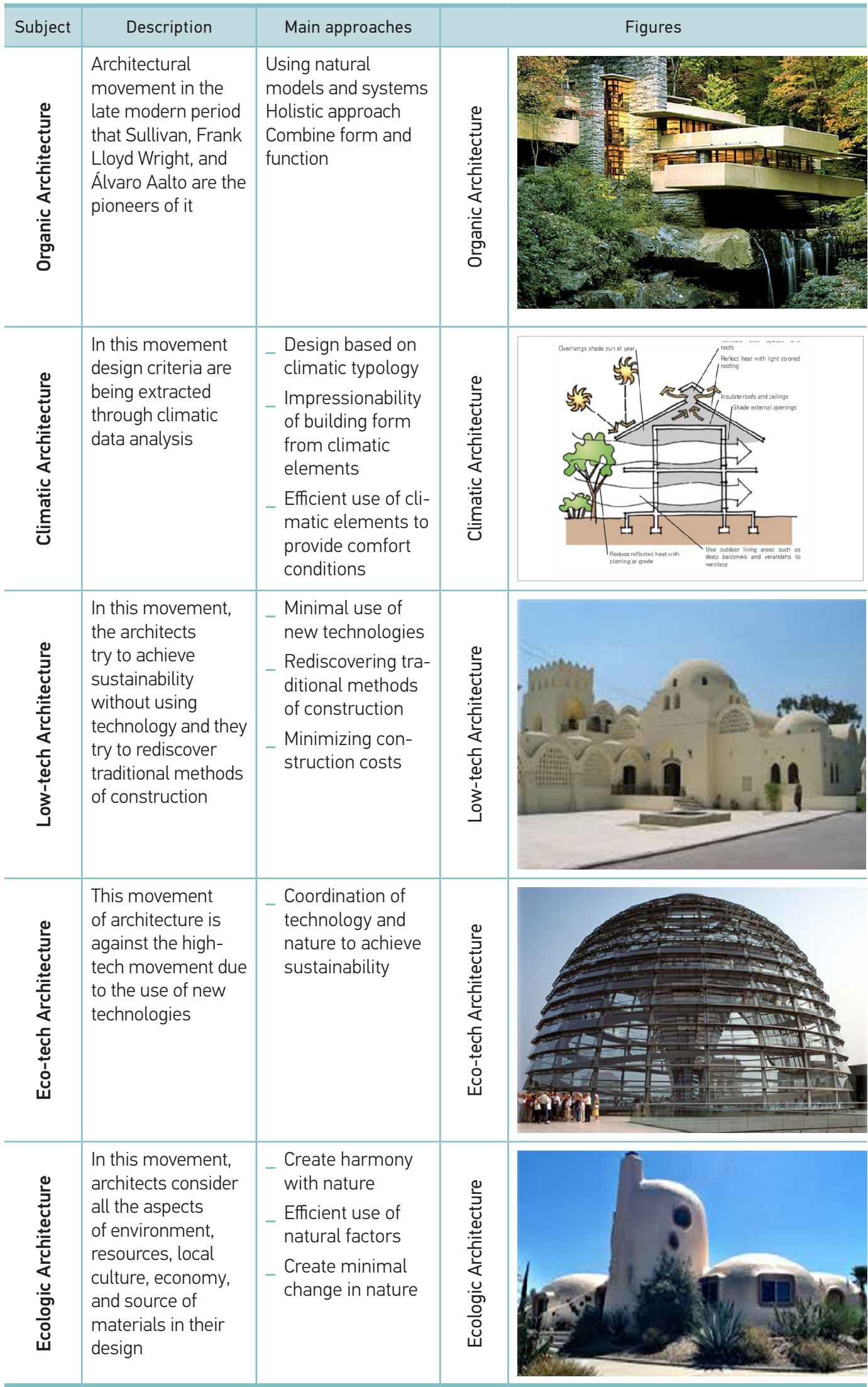


tecture principles and approaches of each are provided. Although approaches and design methods of various movements in the field of sustainable architecture are different, they follow the same principles that are saving resources, design based on life cycle and human design in order to move within the framework of these principles, tools, strategies and techniques both in construction and in the exploitation phase were developed and have been mentioned in the Table 2. However, in the field of design, building information modelling process and related applications, as a suitable context, can help designers and programmers assess the sustainability of design in the early stages of a project. Therefore, we begin to explore the capabilities of this process in order to achieve sustainability in architectural design. It should be noted that in addition to environmental issues, considering the context of a project, cultural features, vernacular architecture, and economic issues play an important role in achieving sustainability objectives in architecture. Subsequently the objectives of the sustainable architecture can be reviewed in three following dimensions:

\begin{tabular}{|c|c|c|c|}
\hline \multirow{10}{*}{ 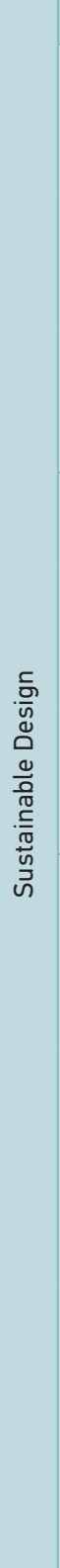 } & Principles & Guidelines & Methods \\
\hline & \multirow{3}{*}{$\begin{array}{l}\text { Economy of } \\
\text { Resources }\end{array}$} & $\begin{array}{l}\text { Energy } \\
\text { Conservation }\end{array}$ & $\begin{array}{l}\text { _ Energy conscious planning } \\
\text { _- Alternative source of energy } \\
\text { _ Passive heating and cooling systems }\end{array}$ \\
\hline & & $\begin{array}{l}\text { Water } \\
\text { Conservation }\end{array}$ & $\begin{array}{l}\text { Reduce consumption trough indigenous landscaping and use of } \\
\text { related equipment } \\
\text { _ } \text { Reuse trough rainwater and grey water collection }\end{array}$ \\
\hline & & $\begin{array}{l}\text { Material } \\
\text { Conservation }\end{array}$ & $\begin{array}{l}\text { _ Material conservation design and construction } \\
\text { _ Proper sizing of building systems } \\
\text { _ } \text { Rehabilitation of existing structures and use of recycled materials }\end{array}$ \\
\hline & \multirow{3}{*}{$\begin{array}{l}\text { Life Cycle } \\
\text { Design }\end{array}$} & $\begin{array}{l}\text { Pre-Building } \\
\text { Phase }\end{array}$ & $\begin{array}{l}\text { - Use recycled and recyclable materials that can be extracted with } \\
\text { minimum use of energy and environmental impacts }\end{array}$ \\
\hline & & $\begin{array}{l}\text { Building } \\
\text { Phase }\end{array}$ & $\begin{array}{l}\text { _ Provide waste separation facilities } \\
\text { _ Use nontoxic materials to protect construction workers } \\
\text { _ Specify regular maintenance with nontoxic cleaners }\end{array}$ \\
\hline & & $\begin{array}{l}\text { Post- } \\
\text { Building } \\
\text { Phase }\end{array}$ & $\begin{array}{l}\text { _ Adapt existing structures to new users and programs } \\
\text { _ Reuse building components and materials } \\
\text { _ Reuse the land and existing infrastructures }\end{array}$ \\
\hline & \multirow{3}{*}{ Human Design } & $\begin{array}{l}\text { Preservation } \\
\text { of Natural } \\
\text { Conditions }\end{array}$ & $\begin{array}{l}\text { _ Understand the impact of design on nature } \\
\text { _ Respect topographical contours } \\
\text { _ Do not disturb the water table } \\
\text { _ Preserve existing flora and fauna }\end{array}$ \\
\hline & & $\begin{array}{l}\text { Urban } \\
\text { Design Site } \\
\text { Planning }\end{array}$ & $\begin{array}{l}\text { _ Avoid pollution contribution } \\
\text { _ Promote mixed use development } \\
\text { _ Create pedestrian pockets } \\
\text { _ Provide for human-powered transportation } \\
\text { _ Integrate design with public transportation }\end{array}$ \\
\hline & & $\begin{array}{l}\text { Design for } \\
\text { Human } \\
\text { Comfort }\end{array}$ & $\begin{array}{l}\text { - Provide thermal, visual, and acoustic comfort } \\
\text { _ Provide visual connection to exterior } \\
\text { _ Provide operable windows } \\
\text { _ Provide clean, fresh air } \\
\text { _ Accommodate persons with differing physical abilities } \\
\text { _ Use nontoxic materials }\end{array}$ \\
\hline
\end{tabular}

\section{Table 2}

Principles, guidelines, and methods of sustainable development 
Environmental objectives: creating superior environmental quality, waste removal, using recycled material

Economic objectives: creating superior values, reducing operation costs, inventing easy production approaches

_ Social objectives: safety, compliance, employing quality and healthy life

In other words, in order to maintain sustainable development objectives in the field of architecture, the design must have the least environmental impacts, should be justified economically and must ensure the user's personal and social health.

Subsequently sustainable buildings should pay respect to climate, humans, civilization, and environment. All three dimensions of sustainable development should be considered through its design and construction process (Azizibabani, 2014).

Building Information Modelling (BIM) is the development and use of a multi-faceted computer software data model to not only document a building design, but to simulate the construction and operation of a new capital facility or a recapitalized (modernized) facility" (GSA, 2007). The result is a data-rich, object-based, intelligent, and parametric digital representation of the facility, from which views appropriate to various user's needs, can be extracted and analyzed to generate feedback and improvement of the facility design (Levy, 2012).

BIM is more than a device or design application because it is so effective in the design and documentation process. Among the advantages of using BIM in the design and construction process, the following items can be mentioned:

The exercise of BIM has led to enhanced productivity, abridged overhead costs, healthier time management, and superior customer-client affairs (Sharma and Gupta, 2016).

The construction trade uses competent modelling to plan, design, organize, and manufacture modules of buildings. The planning and coordination using BIM curtail flaws before execution (Sharma and Gupta, 2016).

BIM contributes time and expenditure savings and superior quality construction services. Assorted BIM tools can be used to put into practice the BIM in construction projects (Arayici and Tah, 2008).

- Design offers can be analyzed with great accuracy, simulations performed quickly, and the performance of the design can be assessed with confidence. All of these promote the capabilities and innovative solutions.

Environmental performance is more predictable and life cycle costs are better understood.

According to the three-dimensional modelling, design is more understandable for employers and beneficiaries.

- Digital product data can be exploited in downstream processes and used for manufacturing and assembly of structural systems (Azhar et al., 2011).

According to the capabilities that BIM provides for designers at different stages of design, it can be considered as a proper device to achieve sustainability (Fani, 2014). BIM can be used in the following items:

Design based on topographic contours.

Investigating the effects of buildings and obstacles on the absorption of sunlight, wind speed, and wind direction in the early stages of design process.

Achieving optimal dimensions in the construction of spaces and equipment and choosing appropriate materials for construction of architectural spaces in order to save energy.

- Analyzing energy consumption patterns in the building and taking necessary decisions in the early design stages. 
Evaluating the effects of climatic factors on the building volume by specifying factors such as the intensity of daylight, wind speed, etc., in the software database.

In order to show the benefits of the BIM based design process the following case studies, which contain sustainable buildings approved by Leadership in Energy and Environmental Design (LEED) certification, have been surveyed. In all three projects BIM based applications have been used to analyze the virtual model of the building from the early stages of the design process and the effects of these evaluations have been implemented in the final design.

\section{Emory University Psychology Center (United States)}

This building, which has an area of 10200 squares meters, was devoted to research and educational use and succeeded in obtaining (LEED) certification in the field of sustainable buildings. Project cost totaled \$ 35 million, was constructed in 16 months, and BIM was used in order to investigate building sustainability during the different stages of design process. The results led to choosing the best options for building orientation, shell, fenestration, and efficient use of daylight (Azhar et al., 2011). Creating the project site BIM model mitigated negative effects on the environment from a shading point of view (Fig. 1). The changes in architectural design as a result of analysis performed on BIM models have been mentioned in the following:

Reducing buildings openings in the west facade.

Reducing the area of the last floor in order to diminish shadow length.

Reducing height of the building.

Because all of the changes were made in the early design stages, the project design did not require additional time and cost.

\section{House in Sonoma, California (United States)}

The building was completed in 2011 and all the buildings energy requirements have been met from renewable sources. A sloping roof provided the necessary space for establishment of photovoltaic panels and solar collectors. Heat is provided through a radiant floor slab and heat pump powered by a roof-mounted solar array. In lieu of conventional air conditioning, summer air is drawn through an insulated, naturally cool plenum below the house and exhausted through clerestory windows and vents near the roof. The foundations were formed using insulated concrete forms (ICFs) and the exterior walls
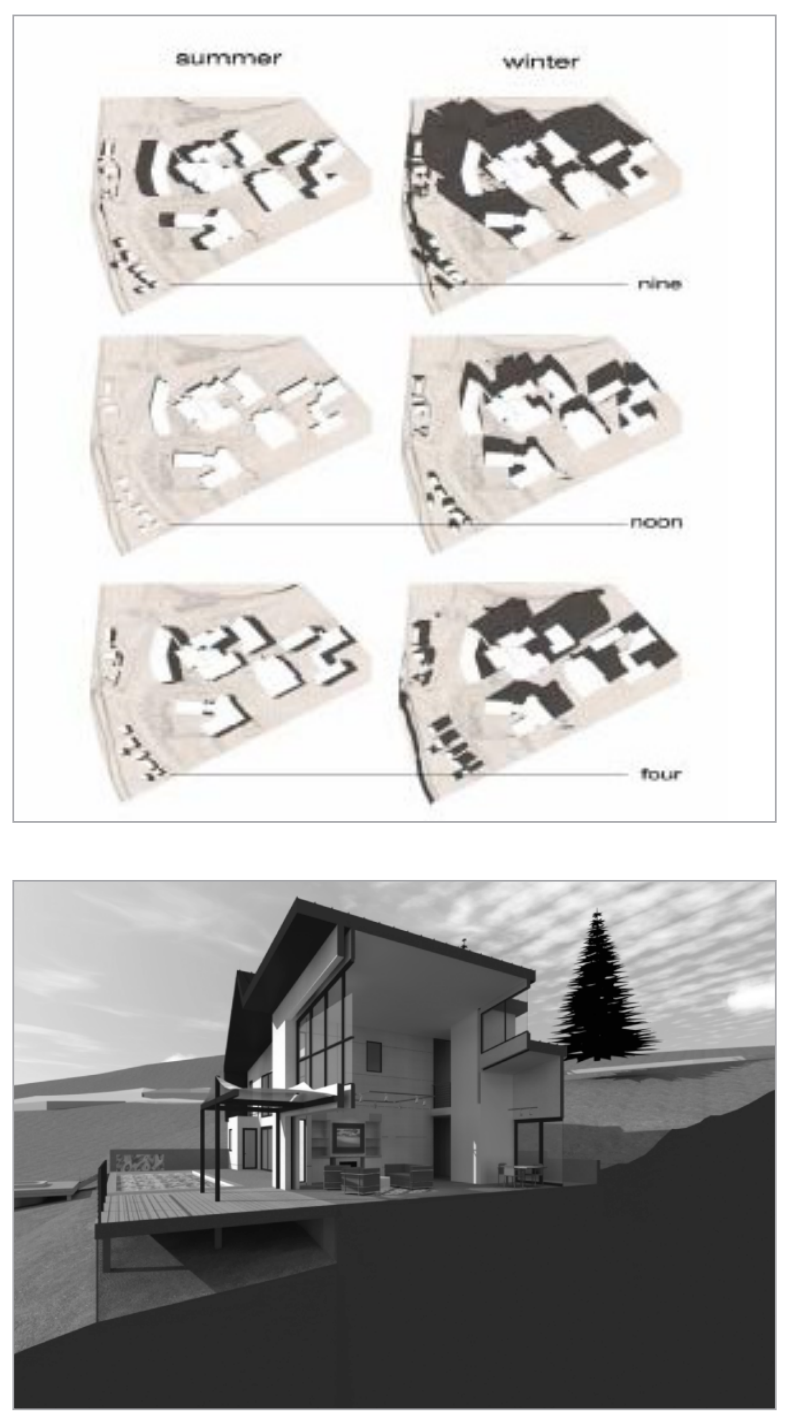

\section{Case Studies}

\section{Fig. 1}

Investigating the effects of building shadow on the site and surrounding buildings (Azhar et al., 2011)

\section{Fig. 2}

Investigation the amount of cut and fill through BIM in order to choose the best choice (Levy, 2012) 
were constructed using a structural insulated panel system (SIPs). This provided a tightly sealed and insulated shell and saved significant time and labor during framing. The exterior doors and windows are thermally broken aluminum with tinted dual glazing. Other key features including a 20,000- gallon rainwater harvesting system and semi-permeable driveway paving to minimize surface water run-off (Levy, 2012).

The BIM was used in the following cases:

Site analysis to understand view lines and topography.

$3 \mathrm{D}$ visualization for the client and the Planning Department.

Sun shadow and ventilation studies.

Preparation and verification of the SIPS shop drawings.

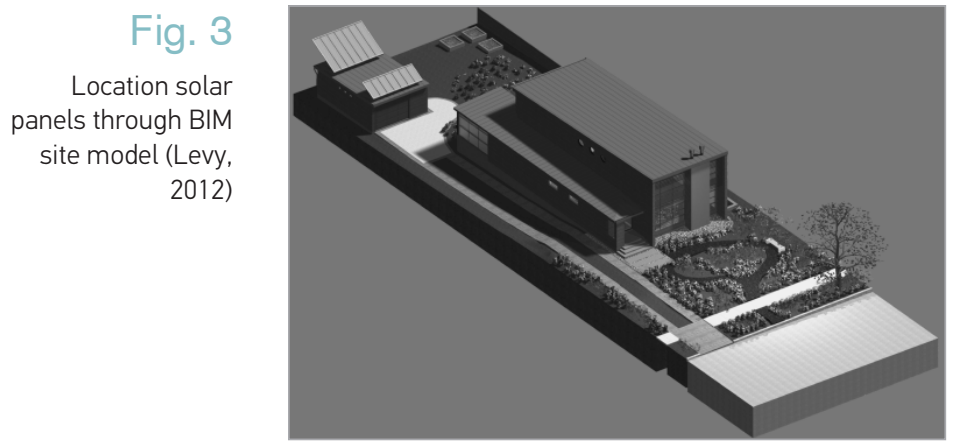

\section{Ross street house, Madison, Wisconsin (United States)}

The concept of this project was that of a carefully controlled light box, and BIM (ArchiCAD) was extensively used in developing the home from its inception to the last stages of design. The form of the building was effected by passive solar design consideration. Several sun studies informed the development of the brise-soleil on the southern elevation of the home and guided the form of the building. The louvers were designed to allow the sun to penetrate deep in to the space between October and February while shading the windows from May to August (Levy, 2012). In order to achieve sustainability goals in the design, studies on BIM models in determining the most appropriate place for the establishment of photovoltaic panels played an important role (Fig. 3). In this regard, in order to minimize the shading on solar panels the BIM model was evaluated in different periods during the year. As a result, these panels provided $58 \%$ of the energy requirements of the buildings. Rainwater was collected in storage tanks or directly used for irrigation of the green spaces. The outer shell of the building was fully insulated, and the ventilation system used was proportional to the surface area and number of stories in the houses. The project met the goals of the program with a simple, well-considered and integrated design solution. The result was a comfortable, livable home with sunlight on the interior surfaces providing passive heating as well as visual excitement throughout the year. The home achieved LEED platinum level certification. This was the first project to do so in the state of Wisconsin (Levy, 2012).

Architectural measures to achieve sustainability can be classified into two main groups. The first one contains measures related to the construction field, which emphasizes using recycled or recyclable materials and renewable energy production active systems to minimize energy and resource consumption. These kinds of measures only support environmental and economic sustainability. The second group are related to the field of design. It is through the design stages that an architect can study the features of the context of the project and take necessary actions. These actions may be in response to the climatic and cultural features or the lifestyle of the users. Some measures like investigating the best orientation for the building, designing passive ventilation systems and choosing the best placement for the active system's equipment are so effective in order 


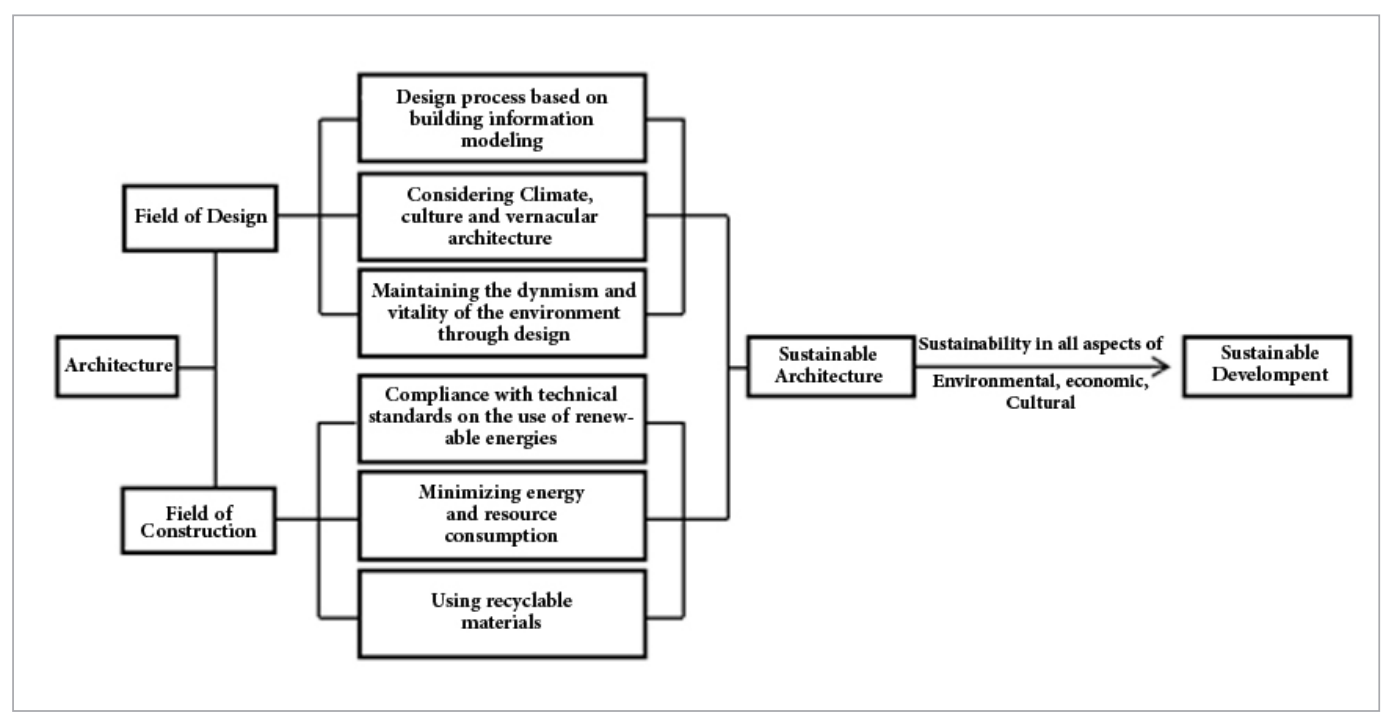

to achieve environmental and economic sustainability and as mentioned it is recommended to use BIM based design process to achieve the best results in this area. However, social sustainability can be achieved in architectural design through maintaining items like vernacular architecture features, user's lifestyle patterns, human health and comfort and protecting physical resources. In the other words, the quality of design is the most important factor that can affect the social sustainability in architecture.

According to the survey of sustainable development, sustainable architecture, and building information modelling concepts and obtained information from analysis of case studies, it was found that the concept of sustainable development shows the importance of addressing this issue in three areas of environmental, economic, and social. So a comprehensive pattern to put architectural activities on the path towards sustainable development has been proposed.

In order to achieve sustainable architecture, all dimensions of sustainable development should be considered in the architectural activities and this is the main difference between sustainable architecture, and some concepts like green architecture or green building that only consider environmental sustainability. In addition to the advantages of using the above pattern in architectural activities, implementation of incentive policies by the relevant authorities in the form of tax credits for sustainable buildings can be a strong incentive to move towards sustainability.

Design and construction approaches regarding the use of renewable energies, natural ventilation and daylight from one side, and building intelligentization and the use of new technologies in order to reduce dependence on non-renewable energy sources on the other side, can directly affect the achievement of environmental sustainability in architecture. Economic benefit and added value that can be achieved in the long term due to the lack of dependence on non-renewable resources in an architectural project, are the aspects of achieving economic sustainability in the field of architecture. Considering civilization and vernacular architecture, maintaining the dynamism and vitality of the environment and designing spaces that are compatible with the culture, behaviors, and methods of human life are the aspects of social sustainability in the field of architecture. The BIM based design process as a new technique to perform various analyzes on the design, can be useful in order to choose the best design alternatives from these points of view: climatic issues, materials and proper orientation, optimal sizes, heating and cooling systems according to user type, and climate and other issues affecting the sustainability plan. Due to the documentation approach of the BIM process in which all aspects of design (architectural, structural and MEP
Fig. 4

Pattern to achieve sustainable development through architecture 
installations) will be considered in a single model, the mismatch errors will be minimized and this will eliminate unforeseen costs in the construction process. Subsequently, architectural design as one of the most effective activities in the field of construction can play an important role to move toward sustainable development, and BIM as a powerful device can provide the necessary context to achieve sustainable design.

\section{References}

Abel, C. Sky high: vertical architecture. London: Royal Academy of Arts; 2003.

Attmann, 0. Green architecture: advanced technologies and materials, New York: McGraw Hill; 2010

Arayici, Y., Tah, J. Towards building information modelling for existing structures. Structural Survey, 2008; 26:210-222. https://doi. org/10.1108/02630800810887108

Azhar, S., Hein, M., Sketo, B. Building Information Modelling (BIM): benefits, risks and challenges. Leadership and Management in Engineering, 2011; 11(3):241-252. https://doi.org/10.1061/(ASCE) LM.1943-5630.0000127

Azizibabani, M. The role of building intelligentization in the process of moving towards sustainable development. Second International Conference on Architecture, Civil Engineering and Urban Planning at the beginning of the third millennium. Tehran; 2016. Available at: http://www.civilica.com/paper-IACUT02-IACUT02_170.html

Azizibabani. M. Binalood renewable energies research center. Master's thesis. Islamic Azad University of Tehran; 2014.

Bauer, M., Mösle, P., Schwarz, M. Green building - guidebook for sustainable architecture. Berlin: Springer; 2010.

Clarke, E. The truth about intelligent buildings. 2008 (accessed 9 May 2015). Available at: http://www. climatechangecorp.com/content.asp?Conten$\mathrm{t} \mid \mathrm{D}=5471$

Edwards, B. A. Rough guide to sustainability. London: RIBA Publications; 2001.

Elington, J. Enter the triple bottom line. In Henriques A., Richardson J. (Eds.) The triple bottom line, does it all add up? Assessing the sustainability of business and CSR London: Earthscan Publications Ltd.; 2004; 1-16.

Fani, F. Application of building information modelling (BIM) in construction project management. The first congress of new technologies to achieve sustainable development, Tehran; 2014.

Gorji, Y. Sustainable architecture and its critique in the field of environment. Journal of the Society of
Architecture and Urbanism of Iran, 2010; 15: 91-100. General Services Administration (GSA). BIM guide series 01, 2007 (accessed April 2017). Available at: www.gsa.gov/graphics/pbs/GSA_BIM_Guide_ v0_60_Series01_Overview_05_14_07.pdf Heerwagen, J., Zagreus, L. The human factors of sustainability: post occupancy evaluation of the Phillip Merrill Environmental Center, Berkeley, CA. University of California Center for the Built Environment; 2005.

Hui, S. C. Low energy building design in high density urban cities. Renewable Energy, 2001; 627-640. https://doi.org/10.1016/S0960-1481(01)00049-0

Kefayati, Z., Moztarzadeh, H. Developing effective social sustainability indicators in architecture. Bulletin of Environment, Pharmacology and Life Sciences, 2015; 40-56.

Levy, F. BIM in mall-cale sustainable design. New Jersey: John Wiley and Sons, Inc.; 2012.

Morelli, J. A definition for environmental professionals. Journal of Environmental Sustainability, 2011; 1(1): Article 2. https:// doi.org/10.14448/jes.01.0002

Murphy, K. The social pillar of sustainable development: a literature review and framework for policy analysis. Sustainability: Science, Practice \& Policy, 2012; 8(1):15-29.

Sassi, P. Strategies for sustainable architecture. New York: Taylor \& Francis; 2006.

Sharma, P., Gupta, S. Applicability of building information modelling (BIM) in Indian built environment sector. American Journal of Engineering and Technology Management, 2016; 1(3): 30-37.

Sinopoli, J. Smart buildings system for architects, owners and builders. Burlington (MA): Elsevier, 2010.

Sirija, M., Arch, B. Necessity of sustainability in architectural practices for achieving sustainable development. International Journal of Science and Technology, 2013; 2: 583-587.

Spaiser, V., Ranganathan, S. The sustainable development oxymoron: quantifying and modelling the incompatibility of sustainable development goals. International Journal of Sustainable Development \& World Ecology; 2016. https://doi.org/10.1080/1350 4509.2016.1235624 
UNESCO. Education Sector. Education for Sustainable Development. Paris: United Nations Educational, Scientific and Cultural Organization; 2012.

World Commission on Environment and Development (WCED) (the Brundtland Commission) report, Our Com- mon Future. Chapter 2: Towards Sustainable Development. UN Documents: Oxford University Press; 1987.

Zahedi, Sh., Jafari, Gh. Expansion of the concept of sustainable development. Journal of Humanities Teacher, 2006; 10(.4): 44-76.

\section{MOHAMMADHOSSEIN AZIZIBABANI}

\section{Researcher}

Housing Foundation of Islamic Revolution

Deputy

Urban Housing

\section{Main research areas}

Sustainable architecture, affordable housing design

\section{Address}

Housing Foundation of Islamic Revolution

Tehran, Iran

Tel: +98 $2188955901-10$

E-mail: H.azizi66@hotmail.com

\section{MARJAN DEHGHANI}

Researcher

About the authors

Housing Foundation of Islamic Revolution

Deputy

Urban Housing

\section{Main research area}

Affordable housing design

\section{Address}

Housing Foundation of Islamic Revolution

Tehran, Iran

Tel: +98 $2188955901-10$

E-mail: H.azizi87@hotmail.com 